\title{
New Precambrian time scale
}

\begin{abstract}
The Subcommission on Precambrian Stratigraphy has agreed formally on a chronometric sub. division and nomenclature of the Precambrian, and its recommendation has been ratified by the International Union of Geological Sciences for international use. This article briefly announces the definition and application of the new time scale for immediate international use. More comprehensive reviews are in preparation. The Subcommission is examining further subdivision of the Archaean into eras.
\end{abstract}

\section{Introduction}

For more than two decades, the Subcommission on Precambrian Stratigraphy (SPS) of the International Commission on Stratigraphy (ICS) has developed sequentially a proposal for the subdivision and nomenclature of the Precambrian. This has been accompanied by regular publication of the progress and by calls for discussion and comment, which culminated in the comprehensive review and preliminary proposal by Plumb and James (1986). Comments received from this proposal were reviewed at a meeting of the Subcommission in 1988, and the proposal was refined into a final recommendation. Subsequent postal ballots. first by SPS and then by ICS during early 1989, achieved positive responses well in excess of the required majority of 60 percent, and the proposal was submitted to the International Union of Geological Sciences (IUGS) for ratification at the 28th International Geological Congress. Discussion was deferred until a later meeting in early 1990, at which time IUGS ratified the proposal as the recommended international time scale for the Precambrian and Proterozoic.

The formal definition is given immediately below and is illustrated in figure 1.

\section{Definition}

The Precambrian time scale shall be divided according to the chronometric subdivision illustrated in figure 1 , in which time boundaries have been selected so as to enclose or delimit principal cycles of sedimentation, orogeny, and magmatism, but in which boundaries are defined in years without specific reference to any bodies of rock.

The top of the Precambrian shall be placed at the base of the Cambrian, at a boundary to be determined by the Working Group on the Precambrian-Cambrian Boundary of the Subcommission on Precambrian Stratigraphy (SPS), but the International Commission on Stratigraphy (ICS) requests that the Working Group of the Subcommission select a boundary whose isotopic age is capable of being determined. There shall be no defined base to the Precambrian at this stage.-

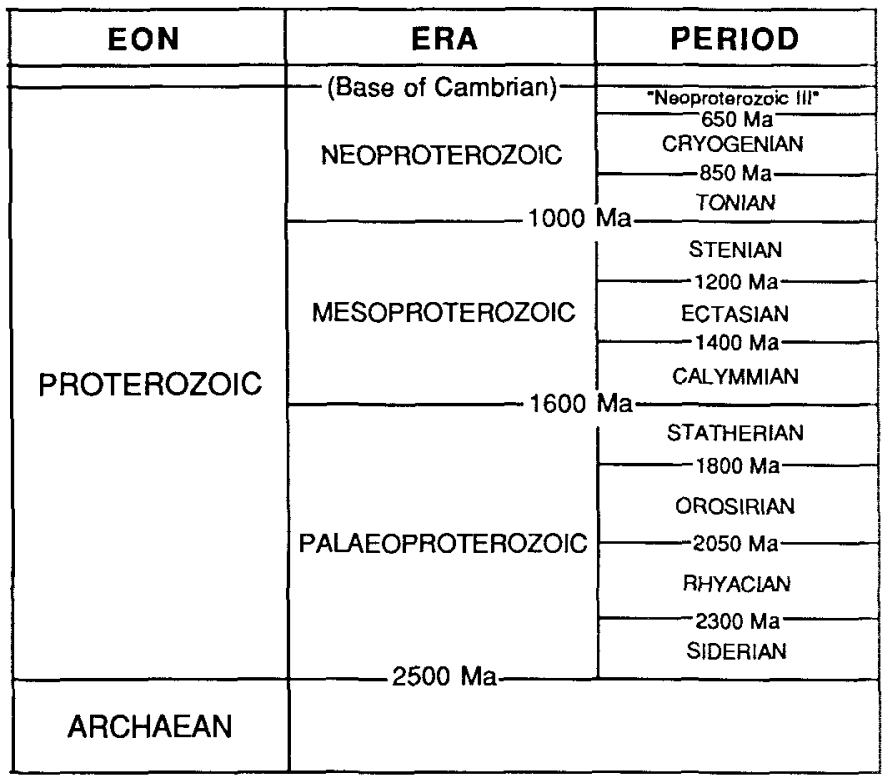

Figure 1.-IUGS-approved chronometric subdivision of Precambrian time and the Proterozoic Eon.

The Precambrian shall be divided into ARCHAEAN (Archean) and PROTEROZOIC Eons. The boundary between them shall be placed at 2,500 Ma, and the top of the Proterozoic shall be placed at the base of the Cambrian (top of the Precambrian).

The Proterozoic Eon shall be subdivided into three eras named. in conformity with nomenclature of the Phanerozoic. from oldest to youngest, the PALAEOPROTEROZOIC. MESOPROTEROZOIC. and NEOPROTEROZOIC, and these shall have boundaries placed at $2,500,1,600$, and 1,000 Ma, and the base of the Cambrian. These eras shall be in turn subdivided into periods as below.

The Palaeoproterozoic shall be subdivided into four periods named, from oldest to youngest, the SIDERIAN, RHYACIAN, OROSIRIAN, and STATHERIAN, and these shall have their boundaries placed at 2,500, 2,300, 2,050, 1,800, and 1,600 Ma.

The Mesoproterozoic shall be subdivided into three periods named, from oldest to youngest, the CALYMMIAN, ECTASIAN, and STENIAN, and these shall have their boundaries placed at 1,600.1,400, J.200, and 1,000 Ma.

The Neoproterozoic shall be divided into three periods. The lower two, with the boundary between them placed at $850 \mathrm{Ma}$, shall be known from older to younger as the TONIAN and CRYOGENIAN. In recognition that, and until, the Working Group on the Terminal Precambrian System (WGTPS) defines and names a new chronostratigraphic unit and stratotype at the top of the Neoproterozoic, the third period shall be known informally as "NEOPROTEROZOIC III," and pending accurate determination of its age, the boundary with the Cryogenian shall be taken provisionally at $650 \mathrm{Ma}$. SPS of ICS requests that WGTPS select a boundary whose isotopic age is capable of being determined. 
Further subdivision of the Archaean (Archean) shall be deferred to some future date pending the collection of more data and analysis by the Subcommission on Precambrian Stratigraphy.

\section{Discussion}

As is clear from the definition above, SPS recommends strictly a chronometric subdivision of Precambrian time, in which boundaries are defined simply by precise isotopic ages that are expressed in years and have neither direct reference to any body of rock nor plus or minus error bars. Rock units should be assigned into that time scale only on the basis of the interpretation or perception of the unit's isotopic age, which is derived from whatever field or laboratory techniques are available (for example, superposition, stratigraphic correlation, and isotopic age determination).

The new nomenclature is unique and thus avoids duplication or confusion with any preexisting time scale or nomenclature. The names are derived from classical Greek roots and, therefore, will transcribe into almost any other language with minimal translation.

The time scale provides a flexible set of subdivision options that are exactly analogous to those available for the Phanerozoic. One may use the formal divisions (for example, Proterozoic, Palaeoproterozoic, and Statherian) at whatever level of precision is appropriate. Alternatively, informal divisions, such as late Proterozoic, early Mesoproterozoic, and middle Stenian, remain available for appropriate situations. Finally, the precise age of a rock body may be expressed directly as a measured isotopic age, if available, in a manner analogous to a precise biostratigraphic zone or finer unit in the Phanerozoic.

The WGTPS has adopted the working principle, in addition to those principles normally required for the selection of boundary stratotypes, that a boundary be defined for the latest Precambrian chronostratigraphic unit whose isotopic age is capable of being de- termined. Because of the likelihood that this unit will be established in the foreseeable future, it would be unnecessarily confusing to formalize another (chronometric) unit of similar age. Therefore, the informal Neoproterozoic III is recommended as an interim measure and is given a provisional age of $650 \mathrm{Ma}$ for its base. The data available currently suggest that the age of the boundary stratotype to be selected is unlikely to differ greatly from this figure.

This article constitutes formal announcement of IUGS s approval and recommendation of the new time scale for international use forthwith. Meanwhile, more comprehensive papers are in preparation, which will detail the principles and development of the new time scale and nomenclature, as well as will discuss their relationship to those being developed for the Phanerozoic. SPS is proceeding actively with the subdivision of the Archaean, and a proposal is anticipated shortly.

\section{Reference}

Plumb, K.A., and James, H.L., 1986, Subdivision of Precambrian time: Recommendations and suggestions by the Subcommission on Precambrian Stratigraphy: Precambrian Research, v. 32, p. 65-92.

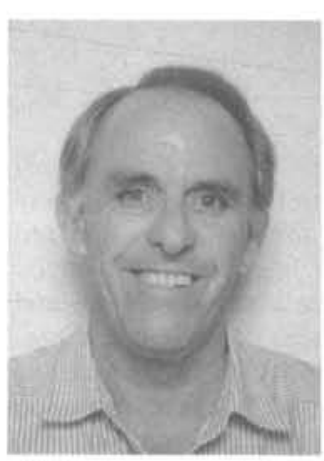

Kenneth A. Plumb has been a Voting Member of the Subcommission on Precambrian Stratigraphy since 1977 and its Chairman since 1984. He has worked with the Bureau of Mineral Resources, Geology, and Geophysics in Canberra, Australia, for over 30 years, where his research has centered on field studies of the regional stratigraphy and tectonic history of the Australian Precambrian, particularly the Proterozoic of northern Australia. 